\title{
22g Cannula - Vascular Occlusion After Nasal Filling with Hyaluronic Acid
}

\author{
Fernanda Bortolozo*, Honório Sampaio Menezes, Danuza Dias Alves, Rodrigo Cadore Ma- \\ faldo, Roberto Chacur, Nívea Bordin Chacur, Leandro Dias Gomes, Raíssa Nardi, Gabriella \\ Andressa Marchesin de Castro, Manuela Guimarães Dias Gomes.
}

Clínica LEGER, Rio de Janeiro, Núcleo de Pesquisa, Brasil

*Corresponding author: Fernanda Bortolozo, Avenida das Américas, 3301-Bloco 4, Sala 301, Barra da Tijuca, Rio de Janeiro/RJ, Brasil

To Cite This Article: Fernanda Bortolozo, Fernanda Bortolozo, Honório Sampaio Menezes, Danuza Dias Alves, Rodrigo Cadore Mafaldo, Roberto Chacur, Nívea Bordin Chacur, Leandro Dias Gomes, Raíssa Nardi, Gabriella Andressa Marchesin de Castro, Manuela Guimarães Dias Gomes. Am J Biomed Sci \& Res. 2021 - 12(4). AJBSR.MS.ID.001762. DOI: 10.34297/AJBSR.2021.12.001762.

Received: 制 April 01, 2021 Published: 些 April 08, 2021

\begin{abstract}
Introduction: Tissue filling, which can be used in some cases of aesthetic dysfunction, may be an alternative to rhinoplasty. The use of dermal fillers can cause some complications depending on the planning, quantity and type of product, and characteristics of each patient. When compared to a needle, cannulas have been described in the literature as a considerably safer alternative to prevent vascular occlusion. Studies have found the $22 \mathrm{G}$ cannula to be the safest.
\end{abstract}

Objective: This study aimed to report a case, not described in the literature thus far, of late vascular occlusion in the nose caused by a tissue filler despite the use of a $22 \mathrm{G}$ cannula.

Methodology: This is a case report of vascular occlusion after a nasal filling using a 22G cannula.

Conclusion: The use of a $22 \mathrm{G}$ cannula in facial filling, in spite of being safer than needles, can also cause vascular occlusion.

Keywords: Hyaluronic acid; Vascular occlusion; 22G cannula; Complication; Tissue fillers; Rhinomodelation.

\section{Introduction}

Rhinoplasty is a delicate surgery that requires a lot of skill and experience from the plastic surgeon. In addition to choosing the professional, the patient must also consider factors of extreme importance, such as the high cost of the procedure, recovery time, possible interruption of daily activities, etc. [1].

Bearing in mind these considerations, the number of nonsurgical aesthetic procedures has grown considerably around the world [2]. Tissue filling can be an alternative to rhinoplasty. Known as rhinomodelation, it can be used in some cases of aesthetic dysfunctions. For this technique, either hyaluronic acid (HA) or polymethylmethacrylate (PMMA) can be used as fillers [2,3].
The use of soft-tissue fillers can cause some complications depending on the planning, quantity and quality of the product, and characteristics of each patient. Among the mildest complications there are edema, erythema, and hematoma. Moderate complications, such as overcorrection, Tyndall effect, and granuloma formation, can also be observed. Moreover, even though they are significantly less common events, more serious complications, such as anaphylaxis, stroke, and local necrosis, may occur. Regarding the most serious adverse outcomes, vascular occlusion, which can lead to necrosis, was the most prevalent [4-9].

When a vascular occlusion occurs, it is usually at the time of the procedure and, thus, the signs of this complication are detected 
by the responsible doctor. Hitherto, there are not studies showing vascular compression as a possible cause of necrosis days after the procedure.

In order to reduce the risks of this type of procedure, several safety protocols are followed. When compared to a needle, cannulas have been described in the literature as a considerably safer alternative to prevent vascular occlusion, because they have atraumatic, blunt tips. The $22 \mathrm{G}$ cannula has been found the safest. To date, there is no scientific evidence showing that soft-tissue filling done with a $22 \mathrm{G}$ cannula can cause vascular occlusion. Nevertheless, in this study, a clinical case in which there was vascular occlusion using this cannula size will be presented [10].

\section{Methodology}

This is a retrospective study of the clinical medical records of a patient who had vascular occlusion after undergoing a nose filling procedure with hyaluronic acid using a $22 \mathrm{G}$ cannula. The patient authorized the use of the information by signing an Informed Consent Form. This study was approved by the Veiga de Almeida University Research Ethics Committee under protocol number 43306620.4.0000.5291.

\section{Clinical Case}

A 43-year-old female patient was injected with $1 \mathrm{~mL}$ of hyaluronic acid (Rennova Ultra-Deep-Lido). The filler was distributed using a $22 \mathrm{G}$ cannula in the nasal dorsum, tip, and columella. Entry points on the nasal dorsum and lower columella region were done using $0.1 \mathrm{~mL}$ of $2 \%$ lidocaine without vasoconstrictor. Fourteen days after, $0.1 \mathrm{~mL}$ of hyaluronic acid (Rennova Lift) was injected in the columella for greater projection of the nasal tip. The procedure was carried out with no complications or signs of tissue distress. On the third day after the injection, the patient started to feel pain in the left nasal ala and contacted the clinic.

The patient was seen by the doctor immediately. She had 1 $\mathrm{cm}$ of gray skin on the left nasal ala with an erythematous halo across the nasal tip and columella. Hyaluronidase (1000UI) was injected followed by local massage. Immediately after it, blood flow returned to the ischemic area, leaving an erythema. The patient was prescribed acetylsalicylic acid (ASA) $300 \mathrm{mg} /$ day, prednisone 40 $\mathrm{mg} /$ day, amoxicillin $875 \mathrm{mg}$ + clavulanate potassium $125 \mathrm{mg}$ for 7 days. Fifteen days after the beginning of the treatment, the patient had recovered fully without sequelae Figure1.

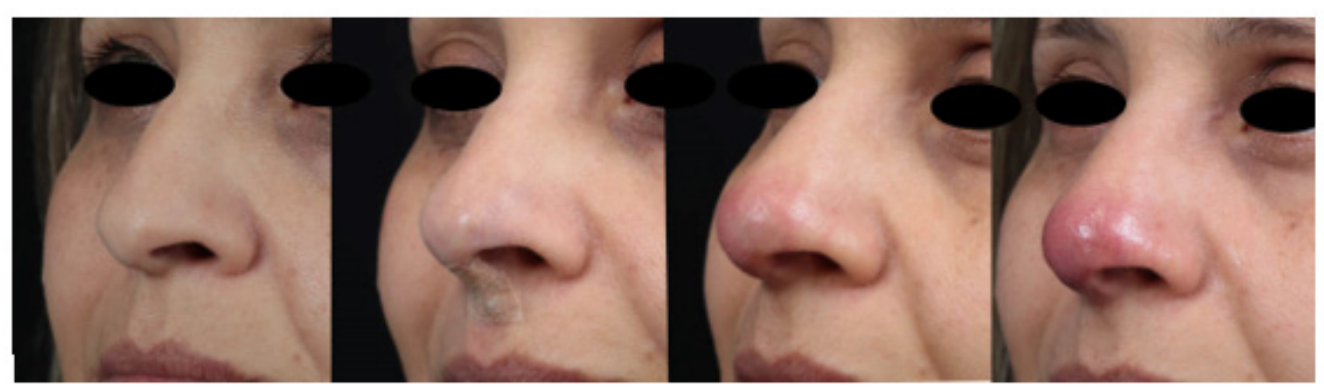

Figure 1: (A) pre-procedure - day 0; (B) immediately after first hyaluronidase injection - day 0; (C) immediately after touch-up injection - day 14; (D) 17 days after injections.

\section{Discussion}

According to the literature and the experience of several professionals, the use of $22 \mathrm{G}$ cannulas for injectable procedures is safer than needles, as those entail a lower risk of bursting a blood vessel and causing vascular occlusion [11].

As demonstrated in this report, vascular occlusion can happen three days after the injection of the tissue filler. It is believed that the overhydration caused by hyaluronic acid could be responsible for late occlusion, as well as extrinsic compression of the angular artery and lateral nasal artery branch.

Even though reperfusion is not guaranteed, early diagnosis and immediate initiation of filler dissolution, along with mechanisms of vasodilation, reduction of inflammation, and prevention of infection, allow for better results in the ischemic area in cases of extrinsic compression.
In this study, the patient recovered completely, with no sequelae, from the ischemic event related to the rhinomodelation with hyaluronic acid.

\section{Conclusion}

This study demonstrated that late vascular occlusion of the lateral nasal artery branch can happen even with the use of the cannula size recommended by current studies. Although the use of a $22 \mathrm{G}$ cannula may prevent intravascular injection of the product, late extrinsic compression should be considered by the doctor, and treatment should be carried out as early as possible.

\section{References}

1. Beck DO, Kenkel JM (2014) Evidence-based medicine: Rhinoplasty. Plast Reconstr Surg 134(6): 1356-1371.

2. Badin Azd (2005) Cirurgia da face e procedimentos ancilares. São Paulo, Atheneu. 
3. Regis Filho GI (2004) Ergonomia aplicada à odontologia. Editora Maio Curitiba.

4. Beasley KL, Weiss MA, Weiss RA (2009) Hyaluronic acid fillers: a comprehensive review. Facial Plast Surg 25(2): 86-94.

5. DeLorenzi C (2013) Complications of injectable fillers, part I. Aesthet Surg J 33: 561-575.

6. DeLorenzi C (2014) Complications of injectable fillers, part 2: vascular complications. Aesthet Surg J 34: 584-600.

7. Woodward J, Khan T, Martin J (2015) Facial Filler Complications. Facial Plast Surg Clin North Am 23: 447-458.
8. Ferneini EM, Ferneini AM (2016) An Overview of Vascular Adverse Events Associated with Facial Soft Tissue Fillers: Recognition, Prevention, and Treatment. J Oral Maxillofac Surg 74: 1630-1636.

9. FDA Safety Communication. Unintentional injection of soft tissue filler into blood vessels in the face.

10. Pavicic T, Webb KL, Frank K, Gotkin RH, Tamura B, et al. (2019) Arterial Wall Penetration Forces in Needles versus Cannulas. Plast Reconstr Surg 143(3): 504e-512e.

11. Radulesco T, De Bonnecaze G, Penicaud M, Dessi P, Michel J (2021) Patient Satisfaction After Non-Surgical Rhinoplasty Using Hyaluronic Acid: A Literature Review. Aesthetic Plast Surg. 